\title{
From Bound Cells Comes a Sound Mind: The Role of Neuronal Growth Regulator 1 in Psychiatric Disorders
}

\author{
Kyungchul Noh ${ }^{1}$, Jung-Cheol Park ${ }^{2}$, Jung-Soo Han $^{2}$ and Sung Joong Lee ${ }^{1 *}$ \\ ${ }^{1}$ Department of Physiology and Neuroscience, Dental Research Institute, Seoul National University School of Dentistry, \\ Seoul 08826, ${ }^{2}$ Department of Biological Science, Konkuk University, Seoul 05029, Korea
}

Cell-to-cell adhesion is important for maintenance of brain structure and function. Abnormal neuronal cell adhesion and loss of its connectivity are considered a main cause of psychiatric disorders such as major depressive disorder (MDD). Various cell adhesion molecules (CAMs) are involved in neuronal cell adhesions and thereby affect brain functions such as learning and memory, cognitive functions, and psychiatric functions. Compared with other CAMs, neuronal growth regulator 1 (Negrl) has a distinct functioning mechanism in terms of its cross-talk with cytokine receptor signaling. Negr1 is a member of the immunoglobulin LON (IgLON) family of proteins and is involved in neuronal outgrowth, dendritic arborization, and synapse formation. In humans, Negrl is a risk gene for obesity based on a genome-wide association study. More recently, accumulating evidence supports that it also plays a critical role in psychiatric disorders. In this review, we discuss the recent findings on the role of Negr 1 in MDD, focusing on its regulatory mechanism. We also provide evidence of putative involvement of Negrl in other psychiatric disorders based on the novel behavioral phenotypes of Negrl knockout mice.

Key words: Cell adhesion molecule (CAM), Neuronal growth regulator 1 (Negr1), Immunoglobulin LON family (IgLON), Psychiatric disorders, Major depressive disorder (MDD)

\section{INTRODUCTION}

Tight connections between presynaptic bouton and postsynaptic density by cell adhesion molecules (CAMs) are critical to form stable and functional synapses [1-6]. Two types of CAMs, $\mathrm{Ca}^{2+}$ dependent and $\mathrm{Ca}^{2+}$-independent, work as synaptic adhesion molecules in the central nervous system (CNS). Cadherin and selectin are dependent on $\mathrm{Ca}^{2+}$ ion for binding, while members of the immunoglobulin superfamily (IgSF) contribute to establishment and remodeling of neuronal synapses [7-9] in a $\mathrm{Ca}^{2+}$-independent manner. Among IgSF, immunoglobulin LON (IgLON) family proteins function as synaptic adhesion molecules that play

Received February 3, 2020, Revised February 23, 2020,

Accepted February 25, 2020

* To whom correspondence should be addressed.

TEL: 82-2-880-2309, FAX: 82-2-880-2309

e-mail: sjlee87@snu.ac.kr important roles in axonal extension, dendritic arborization, and synaptogenesis during brain development [10-13]. Molecules of the IgLON family including LAMP, OBCAM, neurotrimin, GP55, and AvGP50 have three Ig-like domains and localize to the membrane raft of the Triton-insoluble low-density fraction via a glycosylphosphatidylinositol (GPI)-anchor [14-18]. Among the IgLONs, neuronal growth regulator 1 (Negr1), also named Kilon (a kindred of IgLON), is the most recently characterized IgLON subgroup member $[19,20]$.

Negr 1 is a GPI-anchored membrane protein of $46 \mathrm{kDa}$ with three immunoglobulin-like domains and six putative glycosylation sites (Fig. 1A) [19,20]. Initial studies during mouse development show that Negr 1 expression gradually increases during postnatal brain development and reaches a constant level in adulthood [20-22]. Both immunohistochemistry and western blot analysis confirm that the Negrl protein is expressed in the cerebral cortex and hippocampus of the adult rat [19]. In situ hybridization studies revealed that Negrl mRNA is expressed in the cerebral cortex,
Copyright $\odot$ Experimental Neurobiology 2020. www.enjournal.org
This is an Open Access article distributed under the terms of the Creative Commons Attribution Non-Commercial License (http://creativecommons.org/licenses/by-nc/4.0) which permits unrestricted non-commercial use, distribution, and reproduction in any medium, provided the original work is properly cited. 
B Wild Type

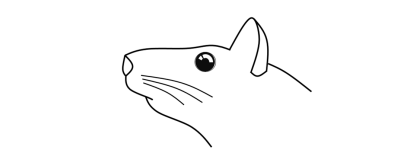

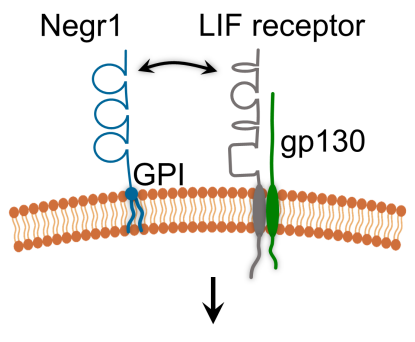

Lcn2 expression

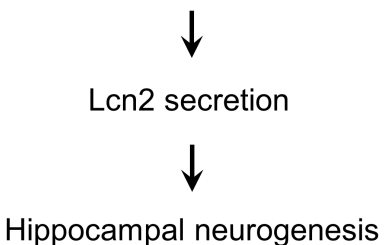

Hippocampal neurogenesis

Normal behaviors
GPI anchored

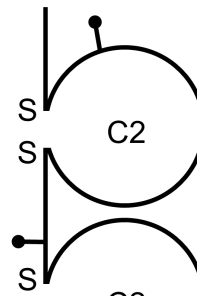

C2

$\mathrm{C} 2$

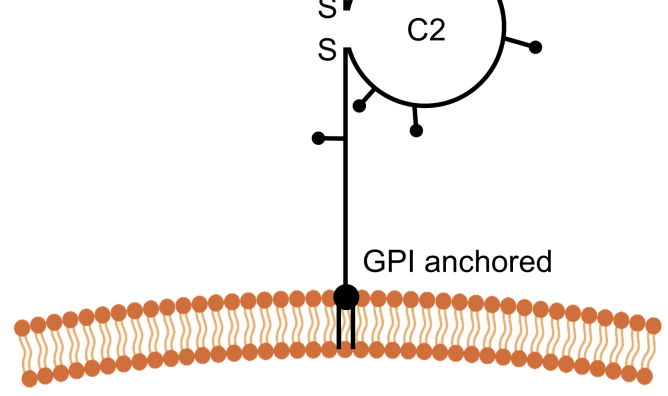

negr1-1-
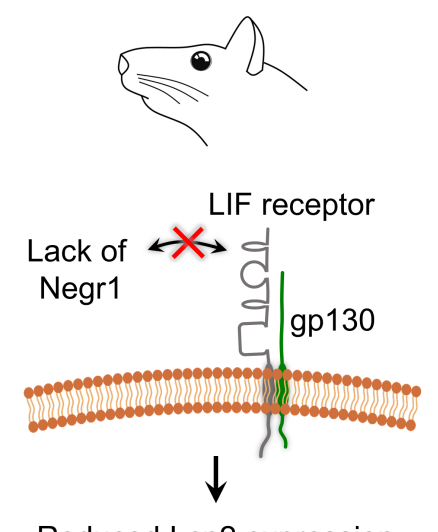

Reduced Lcn2 expression

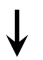

Reduced Lcn2 secretion

Impaired hippocampal neurogenesis

Anxiety / Depression

Fig. 1. (A) Structure of Negr1. Loops represent immunoglobulin-like domains. Lines ending with dots are putative $N$-linked glycosylation sites. (B) Schematic illustration of the molecular mechanism underlying the regulatory role of Negr1 in anxiety- and depressive-like behaviors. Negrl interacts with LIF receptor and potentiates Lcn 2 expression. Lcn2, in turn, induces hippocampal neurogenesis in adult mice. In negr $1^{\digamma}$ mice, impaired adult hippocampal neurogenesis due to reduced Lcn2 expression results in anxiety- and depression-like behaviors.

hippocampus, amygdala, hypothalamus, and olfactory bulb [23]. Moreover, electron microscopic analysis showed specific localization of Negrl at postsynaptic regions of dendritic synapses in the cerebral cortex and hippocampus of the adult brain [22]. In another study, Negr 1 expression was detected in reactive astrocytes, which contribute to neurite outgrowth of hippocampal neurons [21]. These data suggest that Negrl has distinct functions depending on its cellular and subcellular localization in the brain.

\section{ROLE OF NEGR1 IN NEURONAL SYNAPTOGENESIS AND NEU- RITE OUTGROWTH}

The role of Negrl in synaptogenesis and neurite outgrowth has been reported mainly in in vitro studies. Comparing cultured cortical neurons from wild type and Negrl knockout (negr ${ }^{-/-}$) mice, negr $1^{-1-}$ cortical neurons showed significantly reduced neurite numbers, length, and branches [23]. It was suggested that Negrl is shed from the cortical neuronal membrane by metalloproteinase ADAM10 [10], and the soluble form of Negr 1 can promote synaptogenesis and neurite outgrowth [24]. Pischedda and Piccoli [24] showed that membrane-released soluble Negrl promoted neurite outgrowth by modulating ERK1/2 activation and the fibroblast growth factor receptor 2 (FGFR2) signaling pathway as an underlying mechanism. In cultured hippocampal neurons, Negrl was detected mainly in the presynaptic axon terminals in the early culture stage (DIV 3-14); however, at late culture stage (DIV21-28), it was detected mainly in the dendritic postsynaptic spine of mature neurons [25]. This suggests that Negr1 expression and subcellular localization are differentially regulated depending on developmental stage of hippocampal neurons. Moreover, heterologous overexpression of negrl in hippocampal neurons decreased dendritic synapse number at early culture stages (DIV $3-14$ ), whereas it increased dendritic synapses in late culture stages (DIV 21-28) [25]. Together, these studies argue that Negrl differentially modulates neural outgrowth depending on developmental stage [25]. The morphology of neuronal dendritic processes is also affected by Negrl expression [26]. When Negrl expression was knocked-down by miRNA in cultured cortical neurons at DIV 1 , it altered the distribution of neurites in each branching order at a late culture stage (DIV 16) but not at an early culture stage (DIV 6) [26]. Taken together, these results indicate that Negrl is an important regulator of not only synapse number, but also of maturation 
of dendritic processes; moreover, its regulatory effects are dependent on the developing stages of neurons. Direct control by Negr 1 of synapse number and neurite outgrowth was also demonstrated in an in utero study [27]. When negr 1 expression was silenced in mouse embryonic brain at E15.5 by in utero electroporation, dendritic length and number of neurite processes of layer II/III cortical neurons at P7 decreased significantly compared with their controls [27]. These results confirm that Negrl deficiency prevents normal morphological development of pyramidal neurons in vivo.

\section{ROLE OF NEGR1 IN OBESITY}

Since the cloning of negrl, the function of this putative synaptic adhesion molecule has been investigated mainly in synaptogenesis and neurite outgrowth. Therefore, it was unexpected when human genetics studies showed Negr 1 as a major risk factor for human obesity by genome-wide association studies (GWAS) [28-31]. These studies have been replicated in human subjects of various ethnic groups including Europeans [32-37], Asians [38-40], and African Americans $[41,42]$, suggesting that common genetic variants of negr 1 increase the risk of obesity in diverse ethnic backgrounds. Moreover, one animal study demonstrated that increased fat mass, enlarged adipose cells, and decreased muscle mass were observed in negrl-deficient mice [43], suggesting that Negrl may serve as a potential drug target that could be exploited for treatment of human obesity. However, there also were some studies that failed to pinpoint Negrl as an obesity-associated risk factor [44-46]. An obesity risk locus that was identified in obese adults was not related to weight gain of overweight children [44]. Moreover, SNPs of negrl identified in a European population were not related to and had no significant effects in a Chinese population $[45,46]$. Thus, although most reports indicate Negrl as an obesity risk factor, further precise investigation is still needed.

Currently, the molecular mechanisms regarding how Negr 1 serve as a risk factor for human obesity are not clear. Although an in vitro study showed a putative role of Negr 1 in lipid metabolism [43], studies using animal models failed to show any mechanism but rather showed conflicting data. For example, one study showed significantly reduced body mass, food intake, and physical activity in negr $T^{-1}$ mice while energy expenditure remained unchanged [47]. In contrast, another study that targeted Negr 1 expression in a specific brain region showed an opposite phenotype; blocking Negrl expression in the periventricular hypothalamus area in vivo led to increase in body weight and food intake and reduced locomotion activity [48]. Therefore, it can be speculated that Negr 1 expression in the hypothalamus may play a different role in body mass increase compared with that in other brain/body regions.
Therefore, the brain region-specific effects of Negrl polymorphisms on the pathogenesis of obesity need to be addressed.

\section{ROLE OF NEGR1 IN MAJOR DEPRESSIVE DISORDER (MDD)}

Dennis et al. [49] recently reported that Negr 1 has effects on brain structure independent of its effects on obesity. By comparing white matter integrity and SNPs of Negrl in healthy young adults, they concluded that negr 1 was closely associated with low white matter integrity. Considering that precise temporal and spatial expression of CAMs is crucial for development, construction, and maintenance of functional neural connectivity $[5,50,51]$, it is anticipated that Negr 1 may impact the pathogenesis of brain disorders in addition to obesity [52-54], and recent studies suggest that Negrl is implicated in major depressive disorder (MDD).

Maccarrone et. al. [55] screened for a disease-specific protein bio-signature in the cerebrospinal fluid (CSF) of MDD patients and found a significant elevation of Negrl in these patients compared to healthy individuals. The involvement of Negr1 in MDD was also supported by a study screening for putative genetic traits associated with treatment response of selective serotonin reuptake inhibitors (SSRIs) [56] in MDD patients. In this recent cross-trait meta-analysis study, negrl was uncovered as a key genetic locus associated with SSRI responsiveness in MDD patients and was implicated in both obesity and SSRI treatment response [56]. This implies that the genetic variant of obesity is closely linked to SSRI treatment efficacy in MDD. In line with this, aberrant expression of synaptic adhesion molecules was proposed as an etiologic factor of depressive disorder $[57,58]$, and a strong association between SNPs of the limbic system-associated membrane protein (LSAMP) gene and human MDD has been reported [59]. These prior studies suggest that negr 1 may also be involved in psychiatric disorders such as MDD.

To understand the relationship between Negrl and psychiatric disorders, we used negr $1^{--}$mice to test whether Negrl influences affective behaviors such as anxiety and depression [60]. We found that negr $1^{-1-}$ mice exhibit anxiety- and depressive-like behaviors caused by impairment of synaptic transmission of granule cells and neurogenesis in the hippocampal dentate gyrus (DG) [60]. Interestingly, we found that expression of Lipocalin-2 (Lcn2), a $24-\mathrm{kD}$ secretory cytokine [61, 62], is severely compromised in negr $1^{-1-}$ mice, and this Lcn2-decrease is responsible for the cellular and behavioral abnormalities observed in negr ${ }^{-/}$mice [60]. Specifically, heterologous Lcn 2 expression in the DG region of negr $\mathrm{I}^{-/}$mice rescued the abnormal electrophysiological properties of granule cells, impaired hippocampal neurogenesis, and anxiety- and depressive-like behaviors in negr $1^{-/}$mice [60]. Therefore, our data indicate that the 
abnormal affective behaviors observed in negr $1^{-1-}$ mice are due to lack of expression of Lcn2, an immune mediator. In our effort to elucidate the molecular mechanisms underlying the functions of Negrl, we discovered that Negrl directly interacts with leukemia inhibitory factor receptor (LIFR), a co-receptor for LIF [63-65], and thereby potentiates Lcn2 expression [60]. Taken together, our data suggest that Negrl potentiates LIFR-induced Lcn2 expression and thereby affects hippocampal neurogenesis and affective behaviors (Fig. 1B). In previous reports, reduced hippocampal neurogenesis was observed in Lcn2-deficient mice [66], and these mice showed both anxiety and depressive behaviors $[61,62]$, which is in line with our findings. Thus far, both cytokines and synaptic adhesion molecules have been shown to play pivotal roles in MDD and anxiety [67, 68]; however, the cross-talk between these two depression/anxietymediating pathways has not been reported. Consequently, Negrl's function via regulation of the expression of immune mediators is unique compared to other synaptic adhesion molecule functions.

\section{INVOLVEMENT OF NEGR1 IN OTHER PSYCHIATRIC DISOR- DERS AND COGNITIVE FUNCTIONS}

In addition to MDD, Negrl has been implicated in other psychiatric disorders and neurological diseases. Several studies have provided evidence that Negrl is involved in Alzheimer disease (AD)
$[69,70]$, autism spectrum disorder (ASD) [27], and schizophrenia (SCZ) [71]. A GWAS study using patients with comorbid MDD and $\mathrm{AD}$ identified negr 1 as a genetic risk factor that affects AD development [70]. These results suggest a possibility that negr 1 serves as a common risk factor for both MDD and AD pathologies. Furthermore, downregulation of Negrl in mice resulted in impaired behaviors that are similar to those of individuals with ASD [27]. In that study, the authors proposed a putative mechanism by which Negr1-deficiency leads to ASD behavior. According to their proposed mechanism, Negr 1 directly interacts with FGFR2 and cooperatively regulates cortical development. Thus, Negr 1-deficiency led to impaired cortical development resulting in the ASD phenotype. Moreover, a clinical study with schizophrenic patients showed increased expression levels of Negrl transcript in the dorsolateral prefrontal cortex of these patients [71]. Taken together, these studies strongly support that the altered expression of Negr 1 may be associated with abnormal behaviors of various psychiatric disorders (Table 1).

To address the breadth of Negrl influence in psychiatric disorders, we subjected our negr $1^{-1-}$ mice to a series of cognitive tasks assessing spatial memory, recognition memory, and context fear memory. In the spatial version task of Morris water maze for measuring spatial memory, our negr $1^{-1}$ mice performed worse than wild-type mice in locating the hidden platform (Fig. 2A) while

Table 1.Studies showing putative involvement of Negr1 in psychiatric disorders

\begin{tabular}{|c|c|c|c|}
\hline Literature & Disease targeted & Subject & Main findings \\
\hline Singh et al. 2019 [23] & General psychiatric disorders & negr $1^{-1}$ mouse & $\begin{array}{l}\text { - Enlarged ventricle. } \\
\text { - Decreased number of parvalbumin-positive inhibitory } \\
\text { interneurons in hippocampus. } \\
\text { - Hyperactivity in social interaction. } \\
\text { - Impaired social dominance behavior. }\end{array}$ \\
\hline Maccarrone et al. 2013 [55] & $\begin{array}{l}\text { Major depressive disorder (MDD), } \\
\text { Bipolar disorder, } \\
\text { Schizophrenia (SCZ) }\end{array}$ & Human & $\begin{array}{l}\text { - Identification of association of Negrl as a MDD-specific } \\
\text { protein biosignature in cerebrospinal fluid of MDD pa- } \\
\text { tient. }\end{array}$ \\
\hline Szczurkowska et al. 2018 [27] & Autism spectrum disorder (ASD) & negr ${ }^{-/}$mouse & $\begin{array}{l}\text { - Impaired ultrasonic vocalization. } \\
\text { - Increased latency to respond to thermal stimuli. } \\
\text { - Less sniffing, More grooming. }\end{array}$ \\
\hline Ni et al. 2018 [70] & $\begin{array}{l}\text { Major depressive disorder (MDD), } \\
\text { Alzheimer's disease (AD) }\end{array}$ & Human, mouse & $\begin{array}{l}\text { - Identification of Negrl as a common variants in the MDD } \\
\text { GWAS loci with AD. } \\
\text { - Reduced mRNA expression in the entorhinal cortex and } \\
\text { temporal cortex in human AD patient. } \\
\text { - Significant correlation of Negr } 1 \text { mRNA expression level } \\
\text { with both amyloid- } \beta(A \beta) \text { and tau (Tau) burden in AD } \\
\text { mouse model. }\end{array}$ \\
\hline Karis et al. 2018 [71] & Schizophrenia (SCZ) & Human & $\begin{array}{l}\text { - Increased Negrl transcript level in dorsolateral prefrontal } \\
\text { cortex in SCZ patient. }\end{array}$ \\
\hline Noh et al. $2019[60]$ & Major depressive disorder (MDD) & negr $1^{-}$mouse & $\begin{array}{l}\text { - Increased anxiety- and depressive-like behavior. } \\
\text { - Decreased hippocampal neurogenesis. } \\
\text { - Reduced Lipocalin-2 (Lcn2) expression in hippocampus. } \\
\text { - Impaired LTP and mEPSC in hippocampal dentate gyrus. }\end{array}$ \\
\hline Amare et al. 2018 [56] & Major depressive disorder (MDD) & Human & $\begin{array}{l}\text { - Identification of association of Negrl in SSRI treatment } \\
\text { response. }\end{array}$ \\
\hline
\end{tabular}



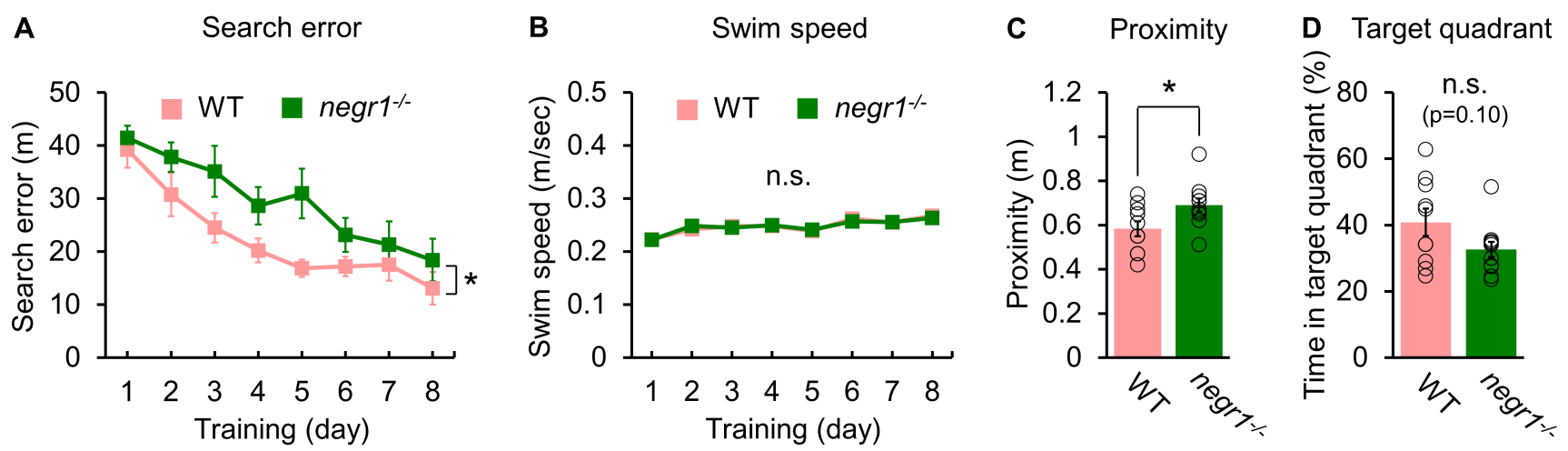

Fig. 2. Spatial memory impairments of negr $1^{-}$mice. To assess the spatial memory of the negr $1^{-}$mice, the Morris water maze task was conducted. (A) The $n e g r 1^{-/}$mice were slower in finding the hidden platform (ANOVA with a repeated measure; Group, $F_{(1,19)}=5.13$, $\mathrm{p}<0.05$; Training $=F_{(7,133)}=17.94$, $\mathrm{p}<0.001$, Group $\mathrm{x}$ Training, $\left.F_{(7,133)}=0.96, \mathrm{p}=0.46\right)$. (B) No differences between the two groups were found in swimming speed during the place training. (C, D) The negr $1^{-1-}$ mice exhibited less spatial bias than the wild-type mice on the probe trial (independent $t$-test; proximity, $t_{(19)}=-2.36$, $p<0.05$; Target quadrant, $\left.t_{(19)}=1.78, \mathrm{p}=0.10\right)$. ${ }^{*} \mathrm{p}<0.05$; n.s., not significant. Data are presented as mean \pm s.e.m.

exhibiting no differences in the swimming speed (Fig. 2B). On the probe trial, the negr $1^{-1}$ mice swam much farther from the hidden platform location than the wild-type mice, as measured by proximity (Fig. 2C). These results indicate hippocampal dysfunction of negr $1^{-1}$ mice because the hippocampus is necessarily recruited for performing the hidden platform version of Morris water maze [72]. Meanwhile, in the novel object recognition, the novel object location, and the contextual fear conditioning task, no differences between negr $1^{-1}$ and wild-type mice were observed, suggesting that Negr 1 expression is not critical for recognition memory or contextual fear memory (Fig. 3). It is interesting that, although negr $1^{-1 /}$ mice exhibited impaired spatial learning and memory, they showed no significant differences in the recognition task or contextual fear conditioning task (Fig. 3). One plausible explanation for these distinct behavioral phenotypes is that Negrl may differentially regulate each neural circuit. Behavioral performance in the Morris water maze depends primarily on the hippocampus region in which Negrl is highly expressed. However, novel object recognition and location tests are affected by both the cerebral cortex and hippocampus [73], and neural circuits between the cerebral cortex and amygdala areas are critical regions for performance in the contextual fear conditioning test [74-76]. Brain regional differences in expression levels of Negrl might have caused different cognitive behavioral performances of negr $1^{-1-}$ mice (spatial learning vs. fear learning; Table 2). Therefore, future studies using optogenetics or conditional knockout mice dissecting the brain regionspecific roles of Negrl are necessary to elucidate the roles of Negrl in other psychiatric disorders.

\section{CONCLUSIONS AND FUTURE DIRECTION}

In this short review, we summarized and discussed recent studies on the role of Negrl in psychiatric disorders. Accumulating evidence based on both human and animal studies support critical roles of Negr1 in psychiatric disorders such as MDD, schizophrenia, and ASD. However, the molecular and cellular mechanisms underlying Negrl's role in these psychiatric disorders remain elusive. Considering the diverse brain expression pattern of Negr 1 including hippocampus, sensory cortex, and prefrontal cortex region, future studies using brain region/cell type-specific negrl conditional knockout mice will be instrumental to elucidate the pathophyisological mechanisms of Negrl in psychiatric disorders. Concerted effort in the fields of genetics, molecular biology, neuroscience, and clinical psychiatric medicine are also needed in the future to dissect the exact pathophysiologic function of this molecule. Although the mechanisms need to be elucidated, studies have proposed Negrl as a novel target for treatment of psychiatric disorders. Considering the high comorbidity between depression and obesity, Negr 1 may act as a central hub bridging the two diseases. If so, Negrl can be a critical common target for treatment of individuals with MDD comorbid with obesity.

\section{ACKNOWLEDGEMENTS}

This work was supported by the Samsung Science \& Technology Foundation (SSTF-BA1502-13).

\section{REFERENCES}

1. Lee SH, Shim J, Kaang BK (2013) The role of cell adhesion 

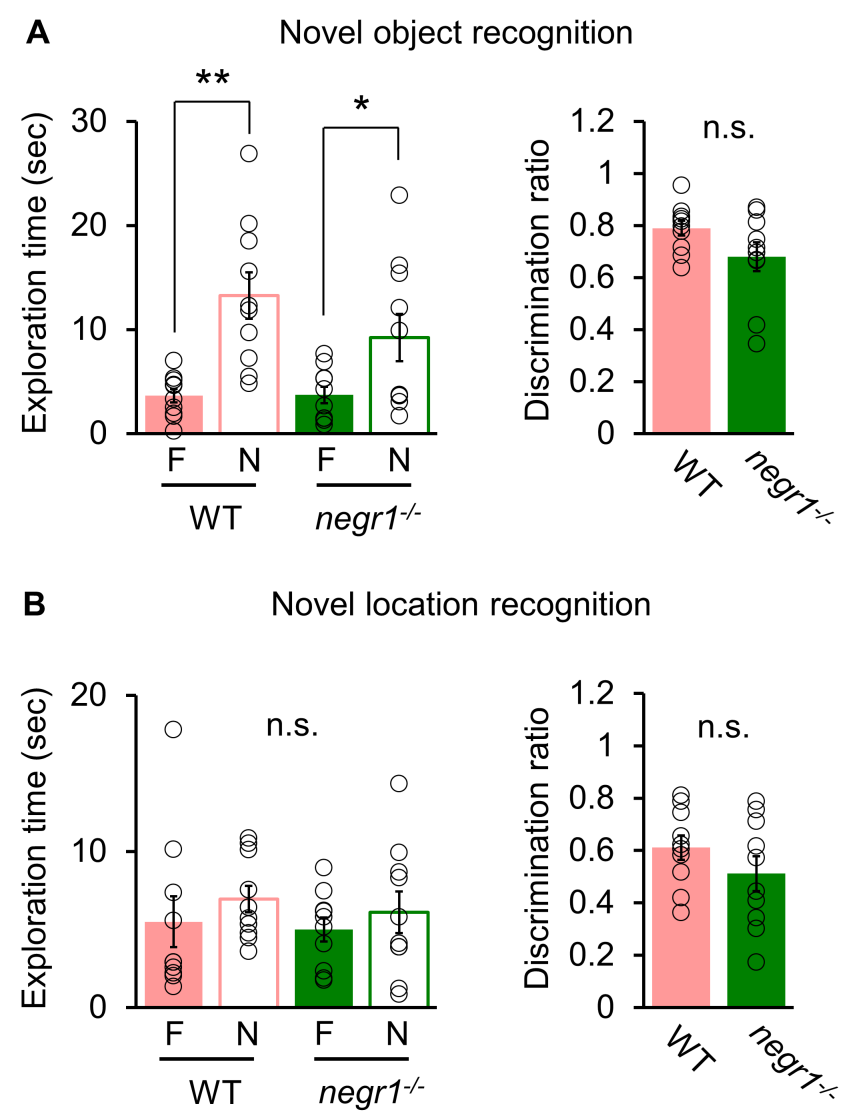

C Contextual fear conditioning

Fig. 3. Performances of the negr ${ }^{-}$and wild-type mice in the object recognition and the contextual fear conditioning task. Novel object recognition and novel location recognition task were performed to measure the recognition memory of negr $1^{-1-}$ mice. (A, left) In the novel object recognition task, both the negr $1^{-/}$and wild-type mice preferred the novel object $(N)$ to the familiar object $(F)$ (paired $t$-test; negr $1^{-\tau_{-}}, t_{(9)}=-2.65$, p $<0.05$; wild-type, $t_{(9)}=-5.06$, $\mathrm{p}<0.05$ ). (A,right) No differences between the two groups were found. (B) In the novel location recognition task, no differences between the two groups in the preference of new location and discrimination ratio were observed. (C) In the contextual fear conditioning task, no differences between the two groups in the freezing levels to context were found. ${ }^{*} \mathrm{p}<0.05 ;{ }^{* *} \mathrm{p}<0.01 ; \mathrm{n}$.s., not significant. Data are presented as mean \pm s.e.m.

Table 2. Cognitive phenotypes of negr $1^{-1}$ mice

\begin{tabular}{llcl}
\hline Types of memory & \multicolumn{1}{c}{ Cognitive tasks } & Results & Involved brain regions \\
\hline Spatial memory & Morris water maze & + & Hippocampus \\
Recognition memory & Novel object recognition & n.s. & Hippocampus, Cerebral cortex \\
Fear memory & Novel location recognition & n.s. & Cerebral cortex, Amygdala \\
\hline
\end{tabular}

+, significant behavior; n.s., not significant.

molecules (CAMs) in defining synapse-specific function and plasticity. Anim Cells Syst 17:1-6.

2. Conant K, Allen M, Lim ST (2015) Activity dependent CAM cleavage and neurotransmission. Front Cell Neurosci 9:305.

3. Takeichi M (1995) Morphogenetic roles of classic cadherins. Curr Opin Cell Biol 7:619-627.

4. Samanta D, Almo SC (2015) Nectin family of cell-adhesion molecules: structural and molecular aspects of function and specificity. Cell Mol Life Sci 72:645-658.

5. Washbourne P, Dityatev A, Scheiffele P, Biederer T, Weiner JA,
Christopherson KS, El-Husseini A (2004) Cell adhesion molecules in synapse formation. J Neurosci 24:9244-9249.

6. Dalva MB, McClelland AC, Kayser MS (2007) Cell adhesion molecules: signalling functions at the synapse. Nat Rev Neurosci 8:206-220.

7. Sytnyk V, Leshchyns'ka I, Schachner M (2017) Neural cell adhesion molecules of the immunoglobulin superfamily regulate synapse formation, maintenance, and function. Trends Neurosci 40:295-308.

8. Zinn K, Özkan E (2017) Neural immunoglobulin superfam- 
ily interaction networks. Curr Opin Neurobiol 45:99-105.

9. Tan RPA, Leshchyns'ka I, Sytnyk V (2017) Glycosylphosphatidylinositol-anchored immunoglobulin superfamily cell adhesion molecules and their role in neuronal development and synapse regulation. Front Mol Neurosci 10:378.

10. Sanz R, Ferraro GB, Fournier AE (2015) IgLON cell adhesion molecules are shed from the cell surface of cortical neurons to promote neuronal growth. J Biol Chem 290:4330-4342.

11. Gil OD, Zanazzi G, Struyk AF, Salzer JL (1998) Neurotrimin mediates bifunctional effects on neurite outgrowth via homophilic and heterophilic interactions. J Neurosci 18:9312-9325.

12. Lodge AP, Howard MR, McNamee CJ, Moss DJ (2000) Colocalisation, heterophilic interactions and regulated expression of IgLON family proteins in the chick nervous system. Brain Res Mol Brain Res 82:84-94.

13. Chen S, Gil O, Ren YQ, Zanazzi G, Salzer JL, Hillman DE (2001) Neurotrimin expression during cerebellar development suggests roles in axon fasciculation and synaptogenesis. J Neurocytol 30:927-937.

14. Pimenta AF, Zhukareva V, Barbe MF, Reinoso BS, Grimley C, Henzel W, Fischer I, Levitt P (1995) The limbic systemassociated membrane protein is an Ig superfamily member that mediates selective neuronal growth and axon targeting. Neuron 15:287-297.

15. Struyk AF, Canoll PD, Wolfgang MJ, Rosen CL, D'Eustachio P, Salzer JL (1995) Cloning of neurotrimin defines a new subfamily of differentially expressed neural cell adhesion molecules. J Neurosci 15(3 Pt 2):2141-2156.

16. Wilson DJ, Kim DS, Clarke GA, Marshall-Clarke S, Moss DJ (1996) A family of glycoproteins (GP55), which inhibit neurite outgrowth, are members of the Ig superfamily and are related to OBCAM, neurotrimin, LAMP and CEPU-1. J Cell Sci 109 (Pt 13):3129-3138.

17. Williams AF, Barclay AN (1988) The immunoglobulin superfamily--domains for cell surface recognition. Annu Rev Immunol 6:381-405.

18. Chothia C, Jones EY (1997) The molecular structure of cell adhesion molecules. Annu Rev Biochem 66:823-862.

19. Funatsu N, Miyata S, Kumanogoh H, Shigeta M, Hamada K, Endo Y, Sokawa Y, Maekawa S (1999) Characterization of a novel rat brain glycosylphosphatidylinositol-anchored protein (Kilon), a member of the IgLON cell adhesion molecule family. J Biol Chem 274:8224-8230.

20. Miyata S, Funatsu N, Matsunaga W, Kiyohara T, Sokawa Y, Maekawa S (2000) Expression of the IgLON cell adhesion molecules Kilon and OBCAM in hypothalamic magnocellular neurons. J Comp Neurol 424:74-85.
21. Schäfer M, Bräuer AU, Savaskan NE, Rathjen FG, Brümmendorf T (2005) Neurotractin/kilon promotes neurite outgrowth and is expressed on reactive astrocytes after entorhinal cortex lesion. Mol Cell Neurosci 29:580-590.

22. Miyata S, Matsumoto N, Taguchi K, Akagi A, Iino T, Funatsu N, Maekawa S (2003) Biochemical and ultrastructural analyses of IgLON cell adhesion molecules, Kilon and OBCAM in the rat brain. Neuroscience 117:645-658.

23. Singh K, Jayaram M, Kaare M, Leidmaa E, Jagomäe T, Heinla I, Hickey MA, Kaasik A, Schäfer MK, Innos J, Lilleväli K, Philips MA, Vasar E (2019) Neural cell adhesion molecule Negr1 deficiency in mouse results in structural brain endophenotypes and behavioral deviations related to psychiatric disorders. Sci Rep 9:5457.

24. Pischedda F, Piccoli G (2016) The IgLON family member Negr1 promotes neuronal arborization acting as soluble factor via FGFR2. Front Mol Neurosci 8:89.

25. Hashimoto T, Yamada M, Maekawa S, Nakashima T, Miyata S (2008) IgLON cell adhesion molecule Kilon is a crucial modulator for synapse number in hippocampal neurons. Brain Res 1224:1-11.

26. Pischedda F, Szczurkowska J, Cirnaru MD, Giesert F, Vezzoli E, Ueffing M, Sala C, Francolini M, Hauck SM, Cancedda L, Piccoli G (2014) A cell surface biotinylation assay to reveal membrane-associated neuronal cues: Negr1 regulates dendritic arborization. Mol Cell Proteomics 13:733-748.

27. Szczurkowska J, Pischedda F, Pinto B, Managò F, Haas CA, Summa M, Bertorelli R, Papaleo F, Schäfer MK, Piccoli G, Cancedda L (2018) NEGR1 and FGFR2 cooperatively regulate cortical development and core behaviours related to autism disorders in mice. Brain 141:2772-2794.

28. Willer CJ1, Speliotes EK, Loos RJ, Li S, Lindgren CM, Heid IM, Berndt SI, Elliott AL, Jackson AU, Lamina C, Lettre G, Lim N, Lyon HN, McCarroll SA, Papadakis K, Qi L, Randall JC, Roccasecca RM, Sanna S, Scheet P, Weedon MN, Wheeler E, Zhao JH, Jacobs LC, Prokopenko I, Soranzo N, Tanaka T, Timpson NJ, Almgren P, Bennett A, Bergman RN, Bingham SA, Bonnycastle LL, Brown M, Burtt NP, Chines P, Coin L, Collins FS, Connell JM, Cooper C, Smith GD, Dennison EM, Deodhar P, Elliott P, Erdos MR, Estrada K, Evans DM, Gianniny L, Gieger C, Gillson CJ, Guiducci C, Hackett R, Hadley D, Hall AS, Havulinna AS, Hebebrand J, Hofman A, Isomaa B, Jacobs KB, Johnson T, Jousilahti P, Jovanovic Z, Khaw KT, Kraft P, Kuokkanen M, Kuusisto J, Laitinen J, Lakatta EG, Luan J, Luben RN, Mangino M, McArdle WL, Meitinger T, Mulas A, Munroe PB, Narisu N, Ness AR, Northstone K, O'Rahilly S, Purmann C, Rees MG, Ridderstråle M, 
Ring SM, Rivadeneira F, Ruokonen A, Sandhu MS, Saramies J, Scott LJ, Scuteri A, Silander K, Sims MA, Song K, Stephens J, Stevens S, Stringham HM, Tung YC, Valle TT, Van Duijn CM, Vimaleswaran KS, Vollenweider P, Waeber G, Wallace C, Watanabe RM, Waterworth DM, Watkins N; Wellcome Trust Case Control Consortium, Witteman JC, Zeggini E, Zhai G, Zillikens MC, Altshuler D, Caulfield MJ, Chanock SJ, Farooqi IS, Ferrucci L, Guralnik JM, Hattersley AT, Hu FB, Jarvelin MR, Laakso M, Mooser V, Ong KK, Ouwehand WH, Salomaa V, Samani NJ, Spector TD, Tuomi T, Tuomilehto J, Uda M, Uitterlinden AG, Wareham NJ, Deloukas P, Frayling TM, Groop LC, Hayes RB, Hunter DJ, Mohlke KL, Peltonen L, Schlessinger D, Strachan DP, Wichmann HE, McCarthy MI, Boehnke M, Barroso I, Abecasis GR, Hirschhorn JN; Genetic Investigation of ANthropometric Traits Consortium (2009) Six new loci associated with body mass index highlight a neuronal influence on body weight regulation. Nat Genet 41:25-34.

29. Zhao J, Bradfield JP, Li M, Wang K, Zhang H, Kim CE, Annaiah K, Glessner JT, Thomas K, Garris M, Frackelton EC, Otieno FG, Shaner JL, Smith RM, Chiavacci RM, Berkowitz RI, Hakonarson H, Grant SF (2009) The role of obesity-associated loci identified in genome-wide association studies in the determination of pediatric BMI. Obesity (Silver Spring) 17:2254-2257.

30. Jarick I, Vogel CI, Scherag S, Schäfer H, Hebebrand J, Hinney A, Scherag A (2011) Novel common copy number variation for early onset extreme obesity on chromosome 11q11 identified by a genome-wide analysis. Hum Mol Genet 20:840-852.

31. Bernhard F, Landgraf K, Klöting N, Berthold A, Büttner P, Friebe D, Kiess W, Kovacs P, Blüher M, Körner A (2013) Functional relevance of genes implicated by obesity genome-wide association study signals for human adipocyte biology. Diabetologia 56:311-322.

32. Mägi R, Manning S, Yousseif A, Pucci A, Santini F, Karra E, Querci G, Pelosini C, McCarthy MI, Lindgren CM, Batterham RL (2013) Contribution of 32 GWAS-identified common variants to severe obesity in European adults referred for bariatric surgery. PLoS One 8:e70735.

33. Poveda A, Ibáñez ME, Rebato E (2014) Common variants in BDNF, FAIM2, FTO, MC4R, NEGR1, and SH2B1 show association with obesity-related variables in Spanish Roma population. Am J Hum Biol 26:660-669.

34. Martínez-García F, Mansego ML, Rojo-Martínez G, De Marco-Solar G, Morcillo S, Soriguer F, Redón J, Pineda Alonso M, Martín-Escudero JC, Cooper RS, Chaves FJ (2013) Impact of obesity-related genes in Spanish population. BMC Genet 14:111.
35. Ntalla I, Panoutsopoulou K, Vlachou P, Southam L, William Rayner N, Zeggini E, Dedoussis GV (2013) Replication of established common genetic variants for adult BMI and childhood obesity in Greek adolescents: the TEENAGE study. Ann Hum Genet 77:268-274.

36. Elks CE, Loos RJ, Hardy R, Wills AK, Wong A, Wareham NJ, Kuh D, Ong KK (2012) Adult obesity susceptibility variants are associated with greater childhood weight gain and a faster tempo of growth: the 1946 British Birth Cohort Study. Am J Clin Nutr 95:1150-1156.

37. Renström F, Payne F, Nordström A, Brito EC, Rolandsson O, Hallmans G, Barroso I, Nordström P, Franks PW; GIANT Consortium (2009) Replication and extension of genomewide association study results for obesity in 4923 adults from Northern Sweden. Hum Mol Genet 18:1489-1496.

38. Hotta K, Kitamoto T, Kitamoto A, Mizusawa S, Matsuo T, Nakata Y, Kamohara S, Miyatake N, Kotani K, Komatsu R, Itoh N, Mineo I, Wada J, Yoneda M, Nakajima A, Funahashi T, Miyazaki S, Tokunaga K, Masuzaki H, Ueno T, Hamaguchi K, Tanaka K, Yamada K, Hanafusa T, Oikawa S, Yoshimatsu H, Sakata T, Matsuzawa Y, Nakao K, Sekine A (2011) Association of variations in the FTO, SCG3 and MTMR9 genes with metabolic syndrome in a Japanese population. J Hum Genet 56:647-651.

39. Cheung CY, Tso AW, Cheung BM, Xu A, Ong KL, Fong CH, Wat NM, Janus ED, Sham PC, Lam KS (2010) Obesity susceptibility genetic variants identified from recent genome-wide association studies: implications in a Chinese population. J Clin Endocrinol Metab 95:1395-1403.

40. Hotta K, Nakamura M, Nakamura T, Matsuo T, Nakata Y, Kamohara S, Miyatake N, Kotani K, Komatsu R, Itoh N, Mineo I, Wada J, Masuzaki H, Yoneda M, Nakajima A, Funahashi T, Miyazaki S, Tokunaga K, Kawamoto M, Ueno T, Hamaguchi K, Tanaka K, Yamada K, Hanafusa T, Oikawa S, Yoshimatsu H, Nakao K, Sakata T, Matsuzawa Y, Kamatani N, Nakamura Y (2009) Association between obesity and polymorphisms in SEC16B, TMEM18, GNPDA2, BDNF, FAIM2 and MC4R in a Japanese population. J Hum Genet 54:727-731.

41. Liu S, Wilson JG, Jiang F, Griswold M, Correa A, Mei H (2016) Multi-variant study of obesity risk genes in African Americans: the Jackson Heart Study. Gene 593:315-321.

42. Hester JM, Wing MR, Li J, Palmer ND, Xu J, Hicks PJ, Roh BH, Norris JM, Wagenknecht LE, Langefeld CD, Freedman BI, Bowden DW, Ng MC (2012) Implication of Europeanderived adiposity loci in African Americans. Int J Obes (Lond) 36:465-473.

43. Joo Y, Kim H, Lee S, Lee S (2019) Neuronal growth regula- 
tor 1-deficient mice show increased adiposity and decreased muscle mass. Int J Obes (Lond) 43:1769-1782.

44. Hinney A, Wolters B, Pütter C, Grallert H, Illig T, Hebebrand J, Reinehr T (2013) No impact of obesity susceptibility loci on weight regain after a lifestyle intervention in overweight children. J Pediatr Endocrinol Metab 26:1209-1213.

45. Ng MC, Tam CH, So WY, Ho JS, Chan AW, Lee HM, Wang Y, Lam VK, Chan JC, Ma RC (2010) Implication of genetic variants near NEGR1, SEC16B, TMEM18, ETV5/DGKG, GNPDA2, LIN7C/BDNF, MTCH2, BCDIN3D/FAIM2, SH2B1, FTO, MC4R, and KCTD 15 with obesity and type 2 diabetes in 7705 Chinese. J Clin Endocrinol Metab 95:2418-2425.

46. Wang J, Mei H, Chen W, Jiang Y, Sun W, Li F, Fu Q, Jiang F (2012) Study of eight GWAS-identified common variants for association with obesity-related indices in Chinese children at puberty. Int J Obes (Lond) 36:542-547.

47. Lee AW, Hengstler H, Schwald K, Berriel-Diaz M, Loreth D, Kirsch M, Kretz O, Haas CA, de Angelis MH, Herzig S, Brümmendorf T, Klingenspor M, Rathjen FG, Rozman J, Nicholson G, Cox RD, Schäfer MK (2012) Functional inactivation of the genome-wide association study obesity gene neuronal growth regulator 1 in mice causes a body mass phenotype. PLoS One 7:e41537.

48. Boender AJ, van Gestel MA, Garner KM, Luijendijk MC, Adan RA (2014) The obesity-associated gene Negr 1 regulates aspects of energy balance in rat hypothalamic areas. Physiol Rep 2:e12083.

49. Dennis EL, Jahanshad N, Braskie MN, Warstadt NM, Hibar DP, Kohannim O, Nir TM, McMahon KL, de Zubicaray GI, Montgomery GW, Martin NG, Toga AW, Wright MJ, Thompson PM (2014) Obesity gene NEGR1 associated with white matter integrity in healthy young adults. Neuroimage $102 \mathrm{Pt}$ 2:548-557.

50. Togashi H, Sakisaka T, Takai Y (2009) Cell adhesion molecules in the central nervous system. Cell Adh Migr 3:29-35.

51. Yamagata M, Sanes JR, Weiner JA (2003) Synaptic adhesion molecules. Curr Opin Cell Biol 15:621-632.

52. Naseer MI, Rasool M, Chaudhary AG, Sogaty S, Karim S, Schulten HJ, Bibi F, Pushparaj PN, Algahtani HA, Al-Qahtani MH (2017) Chromosomal micro-aberration in a saudi family with juvenile myoclonic epilepsy. CNS Neurol Disord Drug Targets 16:1010-1017.

53. Tassano E, Gamucci A, Celle ME, Ronchetto P, Cuoco C, Gimelli G (2015) Clinical and molecular cytogenetic characterization of a de novo interstitial 1p31.1p31.3 deletion in a boy with moderate intellectual disability and severe language impairment. Cytogenet Genome Res 146:39-43.
54. Gamero-Villarroel C, González LM, Gordillo I, Carrillo JA, García-Herráiz A, Flores I, Rodríguez-López R, Gervasini G (2015) Impact of NEGR1 genetic variability on psychological traits of patients with eating disorders. Pharmacogenomics J 15:278-283.

55. Maccarrone G, Ditzen C, Yassouridis A, Rewerts C, Uhr M, Uhlen M, Holsboer F, Turck CW (2013) Psychiatric patient stratification using biosignatures based on cerebrospinal fluid protein expression clusters. J Psychiatr Res 47:1572-1580.

56. Amare AT, Schubert KO, Tekola-Ayele F, Hsu YH, Sangkuhl K, Jenkins G, Whaley RM, Barman P, Batzler A, Altman RB, Arolt V, Brockmöller J, Chen CH, Domschke K, Hall-Flavin DK, Hong CJ, Illi A, Ji Y, Kampman O, Kinoshita T, Leinonen E, Liou YJ, Mushiroda T, Nonen S, Skime MK, Wang L, Kato M, Liu YL, Praphanphoj V, Stingl JC, Bobo WV, Tsai SJ, Kubo M, Klein TE, Weinshilboum RM, Biernacka JM, Baune BT (2019) The association of obesity and coronary artery disease genes with response to SSRIs treatment in major depression. J Neural Transm (Vienna) 126:35-45.

57. Aonurm-Helm A, Jurgenson M, Zharkovsky T, Sonn K, Berezin V, Bock E, Zharkovsky A (2008) Depression-like behaviour in neural cell adhesion molecule (NCAM)-deficient mice and its reversal by an NCAM-derived peptide, FGL. Eur J Neurosci 28:1618-1628.

58. Tchalla AE, Wellenius GA, Sorond FA, Travison TG, Dantoine T, Lipsitz LA (2015) Elevated circulating vascular cell Adhesion Molecule-1 (sVCAM-1) is associated with concurrent depressive symptoms and cerebral white matter hyperintensities in older adults. BMC Geriatr 15:62.

59. Wędzony K, Chocyk A, Maćkowiak M (2013) Potential roles of NCAM/PSA-NCAM proteins in depression and the mechanism of action of antidepressant drugs. Pharmacol Rep 65:1471-1478.

60. Noh K, Lee H, Choi TY, Joo Y, Kim SJ, Kim H, Kim JY, Jahng JW, Lee S, Choi SY, Lee SJ (2019) Negr 1 controls adult hippocampal neurogenesis and affective behaviors. Mol Psychiatry 24:1189-1205.

61. Mucha M, Skrzypiec AE, Schiavon E, Attwood BK, Kucerova E, Pawlak R (2011) Lipocalin-2 controls neuronal excitability and anxiety by regulating dendritic spine formation and maturation. Proc Natl Acad Sci U S A 108:18436-18441.

62. Ferreira AC, Pinto V, Dá Mesquita S, Novais A, Sousa JC, Correia-Neves M, Sousa N, Palha JA, Marques F (2013) Lipocalin-2 is involved in emotional behaviors and cognitive function. Front Cell Neurosci 7:122.

63. Huyton T, Zhang JG, Luo CS, Lou MZ, Hilton DJ, Nicola NA, Garrett TP (2007) An unusual cytokine:Ig-domain interac- 
tion revealed in the crystal structure of leukemia inhibitory factor (LIF) in complex with the LIF receptor. Proc Natl Acad Sci U S A 104:12737-12742.

64. Ernst M, Inglese M, Waring P, Campbell IK, Bao S, Clay FJ, Alexander WS, Wicks IP, Tarlinton DM, Novak U, Heath JK, Dunn AR (2001) Defective gp130-mediated signal transducer and activator of transcription (STAT) signaling results in degenerative joint disease, gastrointestinal ulceration, and failure of uterine implantation. J Exp Med 194:189-203.

65. Müller S, Chakrapani BP, Schwegler H, Hofmann HD, Kirsch M (2009) Neurogenesis in the dentate gyrus depends on ciliary neurotrophic factor and signal transducer and activator of transcription 3 signaling. Stem Cells 27:431-441.

66. Ferreira AC, Novais A, Sousa N, Sousa JC, Marques F (2019) Voluntary running rescues the defective hippocampal neurogenesis and behaviour observed in lipocalin 2-null mice. Sci Rep 9:1649.

67. Cassano P, Bui E, Rogers AH, Walton ZE, Ross R, Zeng M, Nadal-Vicens M, Mischoulon D, Baker AW, Keshaviah A, Worthington J, Hoge EA, Alpert J, Fava M, Wong KK, Simon NM (2017) Inflammatory cytokines in major depressive disorder: a case-control study. Aust N Z J Psychiatry 51:23-31.

68. Vogelzangs N, de Jonge P, Smit JH, Bahn S, Penninx BW (2016) Cytokine production capacity in depression and anxiety. Transl Psychiatry 6:e825.

69. Raghavan NS, Vardarajan B, Mayeux R (2019) Genomic variation in educational attainment modifies Alzheimer disease risk. Neurol Genet 5:e310.

70. Ni H, Xu M, Zhan GL, Fan Y, Zhou H, Jiang HY, Lu WH, Tan L, Zhang DF, Yao YG, Zhang C (2018) The GWAS risk genes for depression may be actively involved in Alzheimer's disease. J Alzheimers Dis 64:1149-1161.

71. Karis K, Eskla KL, Kaare M, Täht K, Tuusov J, Visnapuu T, Innos J, Jayaram M, Timmusk T, Weickert CS, Väli M, Vasar E, Philips MA (2018) Altered expression profile of IgLON family of neural cell adhesion molecules in the dorsolateral prefrontal cortex of schizophrenic patients. Front Mol Neurosci 11:8.

72. Morris RG, Garrud P, Rawlins JN, O'Keefe J (1982) Place navigation impaired in rats with hippocampal lesions. Nature 27:681-683.

73. Barker GR, Warburton EC (2011) When is the hippocampus involved in recognition memory? J Neurosci 31:1072110731.

74. Kochli DE, Thompson EC, Fricke EA, Postle AF, Quinn JJ (2015) The amygdala is critical for trace, delay, and contextual fear conditioning. Learn Mem 22:92-100.

75. Rozeske RR, Valerio S, Chaudun F, Herry C (2015) Prefrontal neuronal circuits of contextual fear conditioning. Genes Brain Behav 14:22-36.

76. Beeman CL, Bauer PS, Pierson JL, Quinn JJ (2013) Hippocampus and medial prefrontal cortex contributions to trace and contextual fear memory expression over time. Learn Mem 20:336-343. 